\title{
Preliminary data on the impact of fish farming facilities on Posidonia oceanica meadows in the Mediterranean
}

\author{
Gérard PERGENT, Stéphane MENDEZ, Christine PERGENT-MARTINI, Vanina PASQUALINI
}

EqEL, Faculty of Sciences, University of Corsica, BP 52, 20250 Corte, France

(Received 15 March 1997, revised 28 April 1998, accepted 5 May 1998)

\begin{abstract}
While the extension of aquaculture along the coasts of the Mediterranean islands is today an economic priority, no data is available on the impact of these facilities on the littoral environment in general, and in particular on the Posidonia oceanica meadows that are responsible for the richness and diversity of these biotopes. The impact of fish farming facilities in the marine littoral environment is assessed at three Mediterranean sites in Corsica and Sardinia. Various parameters are considered: (i) the amount of light available, (ii) the nature of the sediment, and (iii) the vitality of the Posidonia oceanica beds. The findings confirm the impact of the aquaculture facilities within the water column (increase in turbidity, enrichment of the sediment in organic matter and nutrients), and it would appear that the Posidonia oceanica beds also undergo significant alterations. The decline in density of the meadows in the area influenced by aquaculture farming and their total disappearance beneath the facilities is particularly disturbing, even if the areas affected are not very extensive, at least for the smaller farms (a few hundred square metres), and if certain beneficial effects may be recorded (increase in benthic primary production). Because of its ability to record environmental alterations caused by these facilities (light, nutrients, trace metals), the Posidonia oceanica meadow is a good bioindicator for use in monitoring studies. $\odot$ Elsevier, Paris / Ifremer / Cnrs / Ird
\end{abstract}

\section{aquaculture / environment/ seagrass / Posidonia oceanica / Mediterranean}

\begin{abstract}
Résumé - Données préliminaires sur l'impact des installations aquacoles sur les herbiers à Posidonia oceanica en Méditerranée. L'extension des installations aquacoles le long des côtes des îles méditerranéennes est une priorité économique, mais il n'existe pas de données sur l'impact de ces installations sur le milieu littoral, en particulier sur les herbiers à Posidonia oceanica, à l'origine de la richesse et de la diversité de ces biotopes. L'impact des fermes aquacoles, en milieu marin littoral, est évalué dans trois sites méditerranéens, en Corse et en Sardaigne. Les paramètres pris en compte sont la quantité de lumière, la nature du sédiment et la vitalité de l'herbier à Posidonia oceanica. Si les résultats obtenus confirment l'impact des installations aquacoles dans la colonne d'eau (augmentation de la turbidité, enrichissement du sédiment en matière organique et nutriments), il apparaît que l'herbier à Posidonia oceanica subit également des modifications significatives. La diminution de densité des herbiers, dans la zone d'influence des fermes aquacoles, voire leur disparition totale sous les cages, est particulièrement inquiétante même si les zones concernécs sont peu étendues (quelques centaines de mètres) et malgré certains effets bénéfiques (augmentation de la production primaire benthique). Les modifications du milieu engendrées par ses installations (lumière, nutriments, métaux-traces) sont enregistrées par l'herbier à Posidonia oceanica qui apparaît comme un bio-indicateur intéressant à suivre. ( $)$ Elsevier, Paris / Ifremer / Cnrs / Ird
\end{abstract}

aquaculture / environnement / phanérogames marines / Posidonia oceanica / Méditerranée 


\section{INTRODUCIION}

Aquaculture in the Mediterranean (1.6\% of world marine aquaculture production in 1990 [11]) has been developed mainly in the littoral environment (lagoons and inshore areas of sheltered bays). In the marine environment, farming of sea bass (Dicentrarchus labrax Linnaeus 1758) and sea bream (Sparus aurata Linnaeus 1758) is currently expanding at a remarkable rate. However, the scale of production remains decidedly modest in relation to its potential scale and to the natural space available (46000 km of coastline in the Mediterranean). With more than $1000 \mathrm{~km}$ of coastline, much of it highly indented, Corsica, like Sardinia, possesses aquaculture sites of outstanding quality. Fish farming has, in consequence, already achieved a fairly prominent place in the economy of these regions. In Corsica, for instance, aquaculture is the only exporting sector on the island, apart from agriculture [2]. Production was estimated at almost 800 tons of seabass and sea bream in 1993, virtually all of it for export.

Whilst the extension of aquaculture facilities along the coast of the Mediterranean islands remains an economic priority, it is nonetheless essential that it should not entail a significant deterioration of the environment, since this is the basis for tourism in the area. While the environmental impact of intensive marine fish farming has inspired numerous studies at sites in Northern Europe due to the development of salmon farming $[15,24]$, there is virtually no data on the impact of the enrichment of the environment resulting from fish farming in floating cages in the Mediterranean, where this form of activity is more recent. Since the search for suitable sites for aquaculture facilities is on the increase, it seems opportune to identify the parameters that can enable us to assess the impact of these facilities on the littoral environment. While the deleterious effects appear to be similar at different sites and have been clearly identified (enrichment of the water column and substrate in organic matter and dissolved substances; incomplete consumption of food; excretion of nitrogen compounds), their consequences for geographical areas that are exposed to particular climatic conditions, such as narrow bays where the water circulation is slight and subject to violent events (rain, wind), is poorly known. Finally, the impact of aquaculture facilities on the meadows of Posidonia oceanica, which has been a protected species in France since 1988 (decree of 19 July 1988 con cerning the list of protected marine plant species) and in Spain since 1992 [5], has never heen assessed, although this endemic marine seagrass constitutes vast formations from the surface to depths of $40 \mathrm{~m}$, and are the cornerstone of the littoral ecosystems in these regions.

The aim of the present study is therefore to better understand the factors involved and above all to identify the most suitable descriptors for assessing the impact of aquaculture facilities on the littoral environment in general and on Posidonia oceanica meadows in particular.

\section{MATERIALS AND METHODS}

The three aquaculture facilities studied are situated in sheltered, shallow bays, generally in a biotope that favours the development of Posidonia oceanica meadows (figure I).

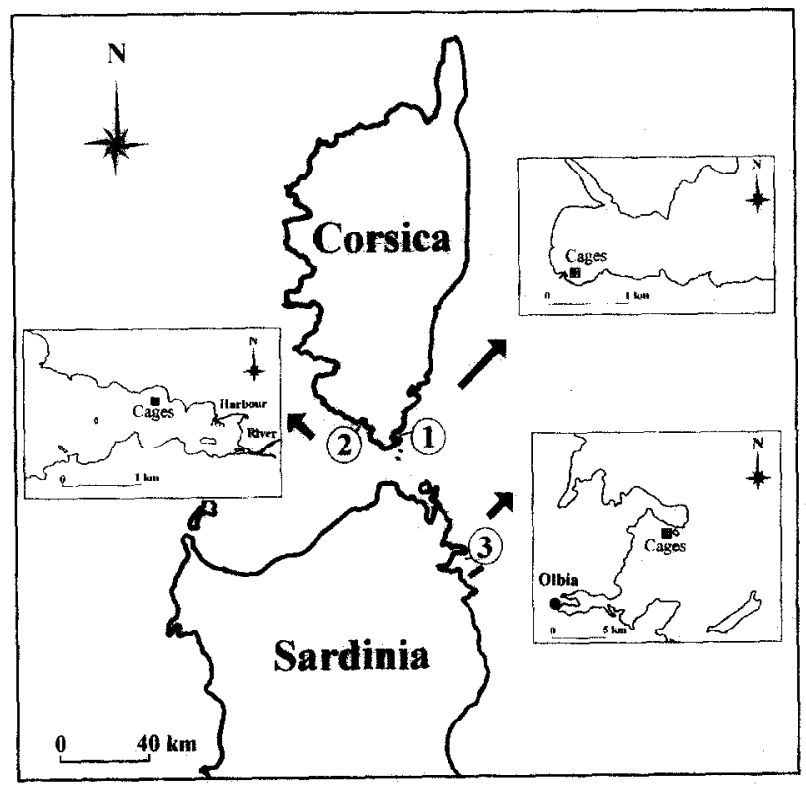

Figure 1. Location of study sites. $1=$ Gulf of Sant'Amanza: 2 = Bay of Figari; $3=$ Gulf of Aranci.

The fish farm in the Gulf of Sant'Amanza (South of Corsica) is situated about $300 \mathrm{~m}$ from the shore. It consists of 20 floating cages (Vitrac system), each with a surface area of $16 \mathrm{~m}^{2}$, spread over an area of one hectare; annual production is estimated at 15 tons (Dicentrarchus labrax and Sparus aurata). The amount of food distributed each year is about 40 tons. These facilities, set up in 1988, are above a bed formed of a mosaic of dead matte and coarse sand; the Posidonia oceanica meadow is situated more than $50 \mathrm{~m}$ from the facilities. Four stations, at depths of 
$6 \mathrm{~m}$, are considered ranging from cages to open sea (table I).

The fish farming facility in the Bay of Figari (South of Corsica) is situated about $200 \mathrm{~m}$ from the shore. The species farmed are the same as at Sant'Amanza, and the production (15 tons) and quantity of food (38 tons) are within the same range. When it was set up (1985), this farm was situated at the edge of a Posidonia oceanica bed, but this seems now to have regressed from beneath the facilities. Six stations at equivalent depths $(10 \mathrm{~m})$ are considered ranging from cages to open sea (table I).

The fish farm in the Gulf of Aranci (Sardinia) is situated about $800 \mathrm{~m}$ from the shore in the lee of a small island. The species cultured are the same as at the other two facilities, but the scale of this farm, started in 1991, is much greater. It consists of $8000 \mathrm{~m}^{2}$ of interconnected floating cages, with a mean annual production of 200 tons. The distribution of food (about 700 tons) is entirely automated (compressed air). This farm was originally installed above a Posidonia oceanica bed, but this meadow has now totally disappeared beneath the facilities. Four stations are considered at a depth of $23 \mathrm{~m}$ (table I).

Measurements and sampling operations were carried out by scuba diving from March to June 1994. The main parameters taken into account are:

\section{The amount of light available}

This is measured by means of a LI-COR (model LI-185 B) quantameter (five replicates per measurement). Two types of measurements were taken: (i) every hour, over a 12-hour daytime cycle (7.30 to 19.30 ) by diving at two stations: FiO and Fi20, and (ii) in the water column, above the lower limit of the Posidonia oceanica meadow.

\section{The nature of the sediment}

Sediment cores were taken using PVC corers $(25 \mathrm{~mm}$ diameter $\times 300 \mathrm{~mm}$ high). For measurements of chloro- phyll $a$ and phaeopigments, only the surface layer $(10 \mathrm{~mm})$ was sampled over an area of about $1 \mathrm{~m}$. Three replicate core samples were taken at each station. For the three sites, the samples were preserved in a ice-box during their transport to the laboratory, where they were immediately sorted.

* Organic matter content: the sediment cores were cut into three fractions: $(0-5 \mathrm{~cm}) ;(5-10 \mathrm{~cm}) ;(10-15 \mathrm{~cm})$, then placed in an oven at $65{ }^{\circ} \mathrm{C}$ for about a week. The dried sediment was weighed before and after a period of five hours at $500{ }^{\circ} \mathrm{C}$, the loss of dry weight is expressed as a percentage of organic matter.

* Nutrient concentrations: wet sediment samples were homogenised and centrifuged. The supernatant (interstitial water) was filtered (Whatman GF/C). The remaining solids (culot) were homogenised and mixed $(40 \mathrm{~mL}$ Normal potassium chloride), then stirred (rotating stirrer). The mixture was then centrifuged, and the supernatant filtered (Whatman GF/C). Samples were then analysed for nitrite and nitrate content (Skalar auto-analyser).

* Trace metal content: concentrations of copper and zinc were measured in the fine sediment fraction of the collected sediment $(0.063 \mathrm{~mm})$ by flame spectrophotometry (3 100 Perkin Elmer) after mineralisation in a microwave oven.

* Chlorophyll $a$ and phaeopigment content: the sediment was conserved under light-free and cool conditions and then spin-dried. The sample of wet sand was then weighed, three replicates $(3 \mathrm{~g})$ were mixed with acetone $(9 \mathrm{~mL}$ at $100 \%)$. The tubes, placed under light-free conditions $\left(5^{\circ} \mathrm{C}, 24 \mathrm{~h}\right)$ were regularly stirred. Chlorophyll $a$ and phaeopigment contents are measured (at 750 and $665 \mathrm{~nm}$ ) before and after acidification (one to two drops of HCL 1 Normal) using a spectrophotometer (Perkin Elmer Lambda2) according to the technique of Strickland and Parsons [34].

Table I. Location of studied sites.

\begin{tabular}{|c|c|c|c|c|c|c|}
\hline \multirow[t]{2}{*}{ Site } & \multirow[t]{2}{*}{ Below cages } & \multicolumn{5}{|c|}{ Distance from cages to open sea } \\
\hline & & $20 \mathrm{~m}$ & $40 \mathrm{~m}$ & $80 \mathrm{~m}$ & $150 \mathrm{~m}$ & $300 \mathrm{~m}$ \\
\hline Sant'Amanza & Sm0 & $\operatorname{Sm} 20$ & & $\operatorname{Sm} 80$ & & Sm300 \\
\hline Figari & Fi0 & Fi20 & Fi40 & $\mathrm{Fi} 80$ & Fi150 & Fi300 \\
\hline Aranci & $\mathrm{ArO}$ & & Ar40 & Ar80 & & $\operatorname{Ar} 300$ \\
\hline
\end{tabular}




\section{The vitality of the meadow}

The density of the meadow (number of shoots per square metre) at each site was assessed by divers using a forty centimetre square quadrat $\left(0.16 \mathrm{~m}^{2}\right)$ placed at random in the seagrass bed (ten replicates). Twenty orthotropic rhizomes of Posidonia oceanica with a living foliar shoot were collected for the purposes of phenological and lepidochronological analyses in the laboratory.

* Phenological study: the foliar shoot was separated from the rhizome, then leaves were detached in the order of insertion according to the technique of Giraud [14]. In this way, two categories of leaf can be identified: (i) adult leaves, of a length greater than $50 \mathrm{~mm}$, with a sheath, and (ii) intermediary leaves, of a length greater than $50 \mathrm{~mm}$, without a sheath. The juvenile leaves were not taken into account. The coefficient A (= percentage of leaves without apex [14]) was calculated. The biomass of the epiphytes was also assessed by scraping the leaves (razor blade), then drying the epiphytes in the oven $\left(60^{\circ} \mathrm{C}\right.$, $48 \mathrm{~h}$ ).

* Lepidochronological analysis: lepidochronology [27], which is related to terrestrial dendrochronology, can be used to accurately retro-date persistent foliar remains (dead sheaths) on the rhizomes of Posidonia oceanica, thanks to the occurrence of chronological cycles of sheath thickness; it is then possible to delimit segments of rhizome corresponding to a given year, and thus to estimate the number of leaves produced per year and the growth rate and production of the rhizome [30]. The rhizomes were cleaned to remove the sediment remaining between the dead sheaths and the epiphytes and macroscopic cpibionts that colonise the rhizome. The dead sheaths of each rhizome were carefully detached according to their insertion rank. Where the thickness of the sheath is at a minimum, the rhizome was cut at the point of insertion of this sheath. One thus obtains a series of rhizome segments, delimited by two thickness minima, each corresponding to a year. The growth rate of the rhizome was estimated on the basis of the mean length (in millimetres) of these segments; the number of leaves produced corresponds to the number of dead sheaths per thickness cycle. The copper and zinc content was analysed by flame spectrophotometry after mineralisation in a microwave oven.

All mean data (results, tables and figures) are given with an indication of the confidence interval $(95 \%)$.

\section{RESULTS AND DISCUSSION}

\subsection{Impact on light availability}

In the Bay of Figari, the values recorded over a period of $12 \mathrm{~h}$ during the month of May show a regular pattern of variation during the day, with a maximum towards midday in proximity to the aquaculture facilities (Station Fi20), and consistently lower values under these last structures (Station Fi0; figure 2). However, the amount of light recorded here is always lower than that recorded in open water at the entrance of the bay (figure 2). This results from the higher turbidity at the head of the bay, probably linked to the outlet of a coastal river estuary and the outflow from a sewage treatment plant as well as to input from the aquaculture facility.

At the station situated directly below the cages, the shadow produced by these facilities may be a second factor at certain times of the day. Nevertheless, the amount of light recorded under facilities at any given time $\left(375 \mu \mathrm{E} \mathrm{m}^{-2} \mathrm{~s}^{-1}\right.$ at $\left.11 \mathrm{~h} 30\right)$ is consistently higher than that recorded at the same moment at lower limit of the meadow ( $96 \mu \mathrm{E} \mathrm{m}^{-2} \mathrm{~s}^{-1}$, at $30 \mathrm{~m}$ depth; figure 2), where light acts as a limiting factor [22]. It is therefore clear that, while there is indeed a reduction in available light under the facilities, this factor alone cannot explain the regression of the meadow observed.

\subsection{Composition of the sediment}

In the gulf of Sant'Amanza, the mean concentrations of organic matter in the sediment $(0-15 \mathrm{~cm})$ exhibit a marked decline (from 5.8 to $1.8 \%$ ) in conjunction with distance from facilities (figure 3). This confirms the enrichment in organic matter of the environment resulting from fish farming $[17,19]$ and its relatively localised character [34]. In the bay of Figari, the mean organic matter concentrations in the sediment (all samples) are much higher than at Sant'Amanza (22.4 $\pm 1.6 \%$ against $3.6 \pm 1.5 \%)$, but relatively constant whatever the distance from facilities. These abnormally high values do not appear to be solely related to the impact of the Figari fish farm, given its low production rate, but more likely result from massive inputs from the river and the sewage treatment plant at the head of the bay.

In contrast, the nitrous acid $\left(\mathrm{NO}_{2}\right)$ content recorded in the interstitial water and the exchangeable ammonium in the sediment from both the Bay of Figari and the Gulf of Sant'Amanza, reveals the existence of a negative gradient 


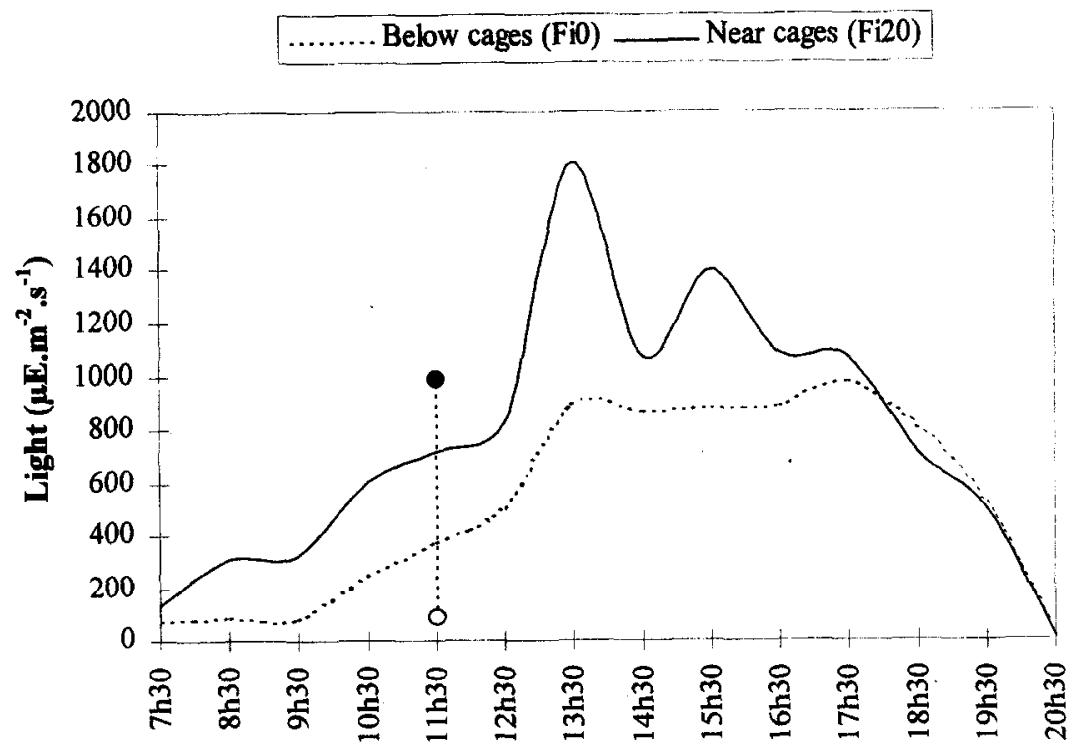

Figure 2. Changes in light availability (expressed in $\mu \mathrm{E} \mathrm{m}^{-2} \mathrm{~s}^{-1}$ ), in proximity to and below facilities of the Figari fish farm, at $10 \mathrm{~m}$ depth, during one daytime cycle in May 1994. = Amount of light recorded at the mouth of the Bay (10 m depth); $O=$ Amount light recorded at the lower limit of the meadow ( $30 \mathrm{~m}$ depth).

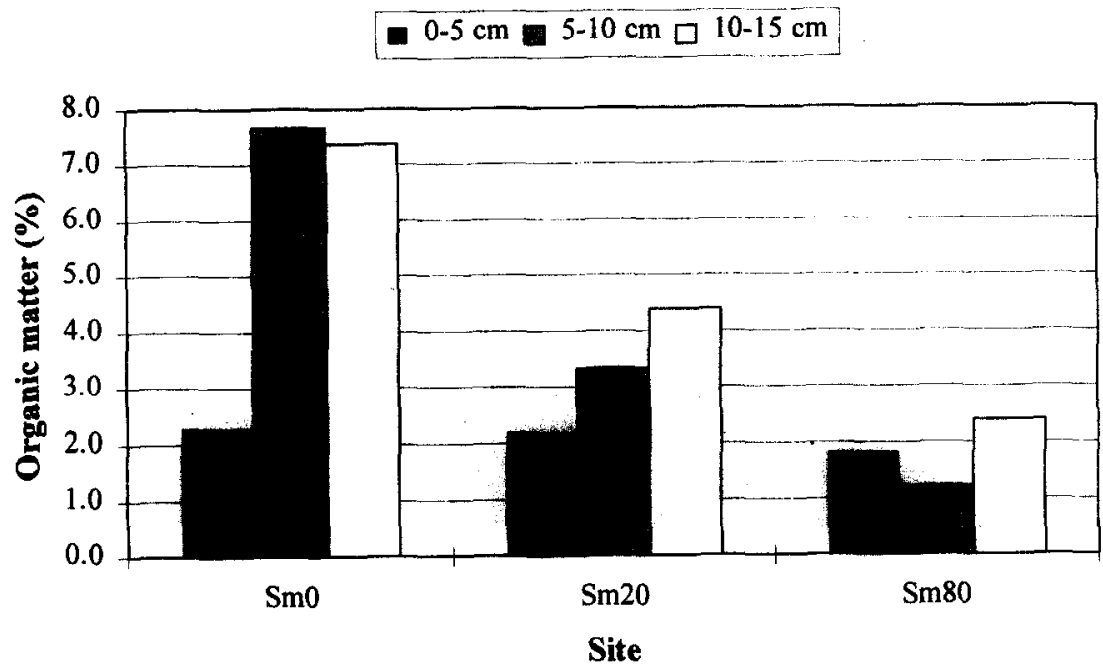

Figure 3. Changes in organic matter content in the sediment in relation to distance from facilities and the depth of sediment sampled at Sant'Amanza in April 1994.

in relation to the distance from the fish farm (figure 4). These high ammonium values may be compared with those recorded in Canada by Grant et al. [16]. It would therefore appear that these two descriptors may provide useful information on the extent of the area affected by the enrichment of the environment resulting from marine fish farming, even when exogenous inputs also play a role. Conversely, the evolution in nitrate level $\left(\mathrm{NO}_{3}\right)$ does not appear to vary as a function of distance from the aquaculture facilities. 


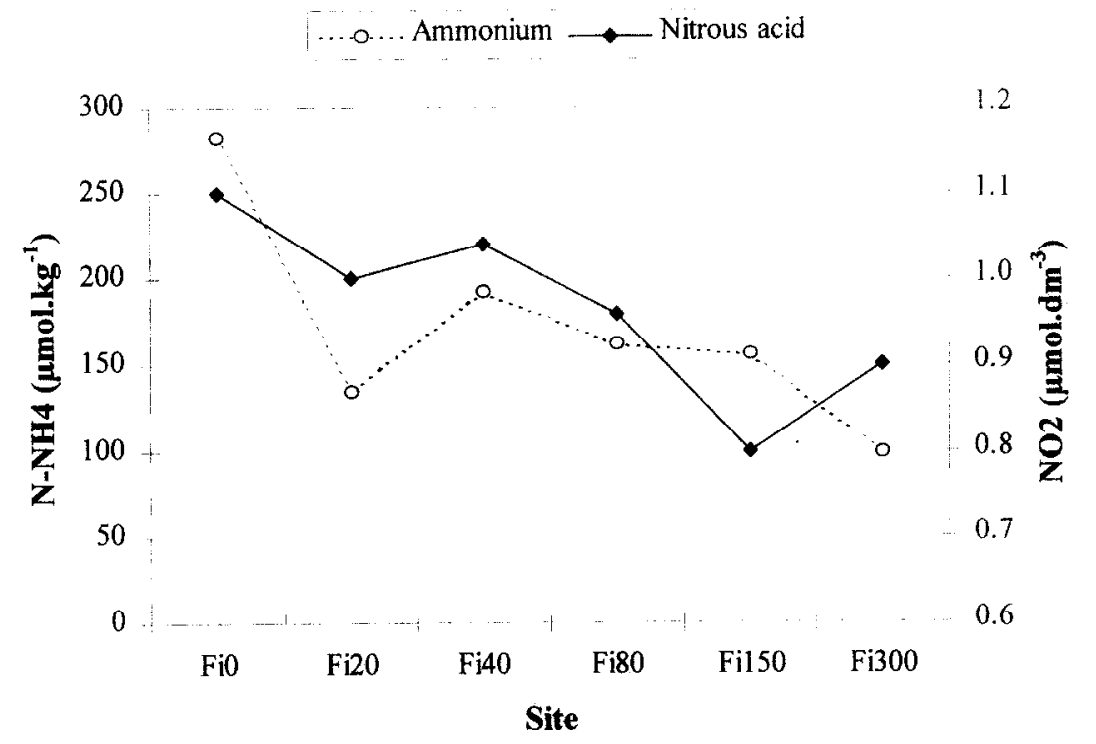

Figure 4. Nitrous acid content (in $\mu \mathrm{mol} \mathrm{dm^{-3 }}$ of interstitial water) and exchangeable ammonium content (in $\mu \mathrm{mol} \mathrm{kg}^{-1}$ of sediment), in relation to the distance from facilities in the Bay of Figari.

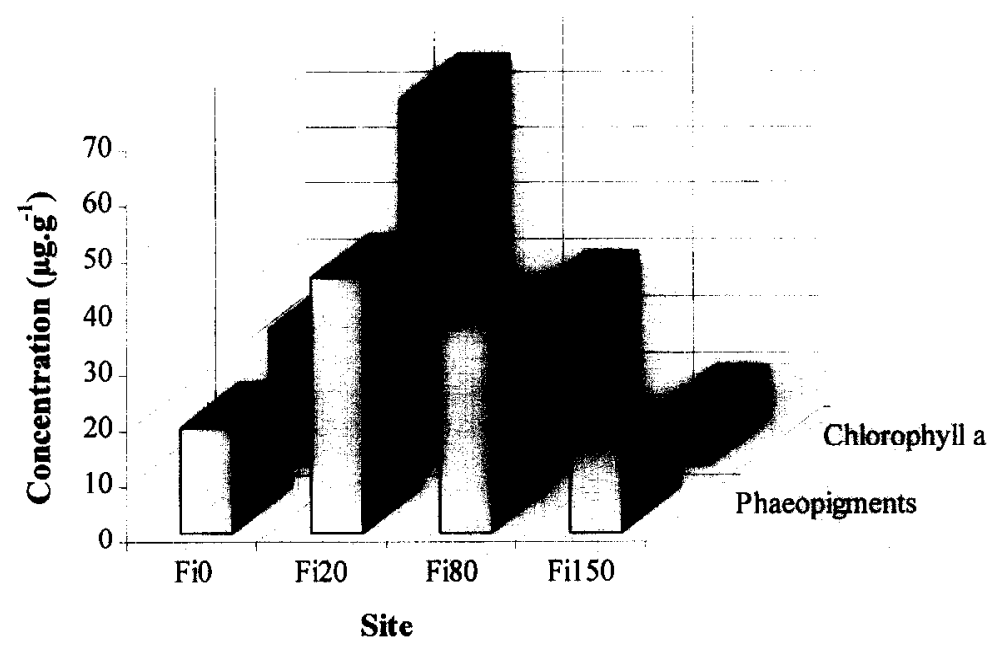

Figure 5. Variations in chlorophyll $a$ and phaeopigments in the sediment surface in relation to the distances from facilities in the Bay of Figari, May 1994.

The feeds given to fish generally contain high levels of copper and zinc (trace metals that play a role in metabolism). Trace metal measurements in the feed most widely used in these fish farms (Super Aquasarb) give copper concentrations of $9.9 \pm 1.1 \mu \mathrm{g} \mathrm{g}^{-1}$ dry weight and zinc concentrations of $118 \pm 3.8 \mu \mathrm{g} \mathrm{g}^{-1}$ dry weight. Nevertheless, and in contrast with what has been observed in the English Channel [23], the concentrations recorded in the sediment show no significant difference as a function of the distance from facilities; they are on average 13.3 \pm 
$2.7 \mu \mathrm{g} \mathrm{g}^{-1}$ for copper, and $433.0 \pm 95.9 \mu \mathrm{g} \mathrm{g}^{-1}$ for zinc. Even if the copper presents a lower concentration, the zinc concentration is of the same order as that recorded in proximity to the sea outflow of the Marseilles municipal urban sewer, namely between 19 and $346 \mu \mathrm{g} \mathrm{g}^{-1}$ for copper and between 64 and $774 \mu \mathrm{g} \mathrm{g}^{-1}$ for zinc [1].

The richness of the sediment in benthic microalgae (e.g. diatoms) is often assessed on the basis of indirect measurements of the pigments involved in photosynthesis. The mean values of chlorophyll $a$ and phaeopigments recorded in the Gulf of Sant'Amanza $\left(4.6 \pm 1.5 \mu \mathrm{g} \mathrm{g}^{-1}\right.$ and $1.1 \pm 0.8 \mu \mathrm{g} \mathrm{g}^{-1}$, respectively) are lower than those recorded in the Bay of Figari $\left(32.3 \pm 16.3 \mu \mathrm{g} \mathrm{g}^{-1}\right.$ and $\left.28.9 \pm 10.1 \mu \mathrm{g} \mathrm{g}^{-1}\right)$. The chlorophyll $a$ values recorded at Figari are closer to those recorded in estuarine silt ( 25 to $34 \mu_{\mathrm{g} \mathrm{g}^{-1}}$ in [21]) than in Posidonia oceanica beds of the Corsican coast (between $0.33 \mu \mathrm{g} \mathrm{g}^{-1}$ and $2.61 \mu \mathrm{g} \mathrm{g}^{-1}$ at Bastia; unpublished data). In the Bay of Figari, the chlorophyll a and phaeopigment levels decrease with distance from the facilities (figure 5). This clearly shows the value of this descriptor in assessing the area influenced by aquaculture facilities. Nevertheless, an abnormally low value can be noted directly beneath the facilities, (Fi0), possibly due to either the inhibitory action of varied wastes (biodeposition, copper concentration) or the physical perturbations caused by the facilities on the development of benthic microalgae (figure 5).

\subsection{Vitality of the meadow}

In the control areas ( $300 \mathrm{~m}$ from facilities), the density of the Posidonia oceanica meadow is higher in the Bay of Figari $(10 \mathrm{~m}$ depth) than in the Gulf of Aranci $(23 \mathrm{~m}$ depth). In addition, at all the sites a decrease in density is apparent closer to facilities (table II). The difference between the two sites may easily be explained by the decrease in light intensity with increasing depth $[12,28]$. For a given site (constant depth), the variations recorded appear to be related to fish farming (turbidity). However,

Table II. Density of Posidonia oceanica meadow (number of shoots per $\mathbf{m}^{2}$ ) at the different stations studied. Values are expressed as mean \pm confidence intervals.

\begin{tabular}{lccc}
\hline Site & \multicolumn{4}{c}{ Distance from facilities to open sea } \\
& $\mathbf{0} \mathbf{~}$ & $\mathbf{8 0} \mathbf{~}$ & $\mathbf{3 0 0} \mathbf{~}$ \\
\hline Figari $(-10 \mathrm{~m})$ & $63 \pm 11$ & $250 \pm 28$ & $313 \pm 41$ \\
Aranci $(-23 \mathrm{~m})$ & $110 \pm 16$ & $175 \pm 29$ & $200 \pm 32$ \\
\hline
\end{tabular}

while the control site in the Gulf of Aranci exhibits normal density for the depth [29], density in the Bay of Figari, on the other hand, is lower, which would appear to indicate a more general source of perturbation (figure 6).

The mcan number of leaves per shoot is fairly homogeneous at the different sites studied; it is at the Gulf of

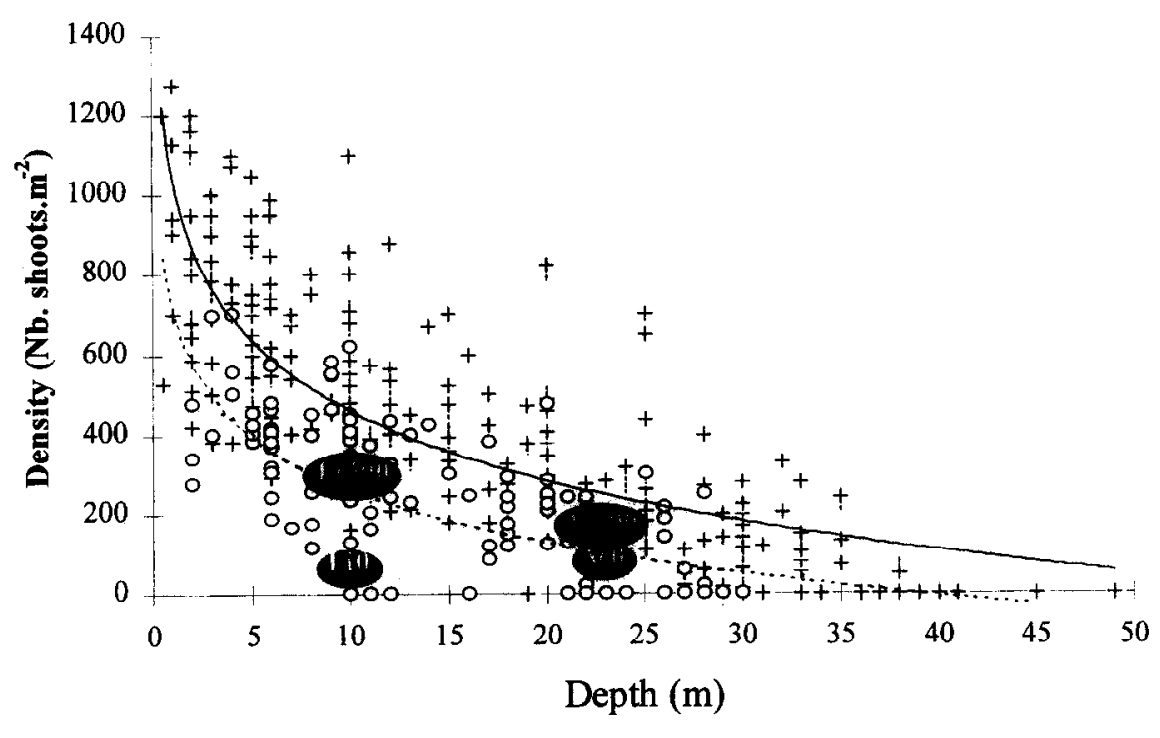

+ Low human pressure

- High human pressure

LHP

HHP

Figure 6. Changes in Posidonia oceanica meadow density in the Mediterranean in relation to the depth and the level of human pressures at the site [29]. Densities recorded in the Bay of Figari and the Gulf of Aranci are reported in relation to the distance from facilities. 
Sant'Amanza (the shallowest station) that these values are highest $(5.4 \pm 0.4)$ and in the Gulf of Aranci (the deepest station) that they are lowest $(4.8 \pm 0.4)$. The relative distance from facilities does not appear to have any significant impact for the shallow stations, whereas there is an increase in this value (from $4.3 \pm 0.5$ to $5.4 \pm 0.4$ ) at the deepest site (table III).

Table III. Number of leaves per shoot (adult and intermediate leaves), in June 1994, according to the distance from facilities. Values are expressed as mean \pm confidence intervals.

\begin{tabular}{lcccc}
\hline Site & \multicolumn{4}{c}{ Distance from facilities to open sea } \\
& $\mathbf{0 ~} \mathbf{~}$ & $\mathbf{4 0} \mathbf{~}$ & $\mathbf{8 0} \mathbf{~}$ & $\mathbf{3 0 0} \mathbf{~}$ \\
\hline Figari $(-10 \mathrm{~m})$ & $4.8+0.4$ & $5.3+0.4$ & $4.8+0.5$ & $4.8+0.5$ \\
Aranci $(-23 \mathrm{~m})$ & $4.3+0.5$ & $4.6+0.5$ & $5.2+0.7$ & $5.4+0.4$ \\
\hline
\end{tabular}

For all the stations studied, the length of the adult and intermediary leaves increases from March to June. This seasonal variation is similar to that observed at other Mediterranean sites [25, 28]. For a given month, the mean length of the leaves (adult and intermediate) decreases when distance from facilities increases (figure 7). By pooling the data obtained from the Fi0 station with that of Fi40 and data from Fi80 with Fi300, it is observed that the length of the adult and intermediary leaves is significantly different (Student test, $t_{\mathrm{adl}}=5.05$, $\left.\mathrm{p}<0.001 ; \mathrm{t}_{\text {int }}=7.38, \mathrm{p}<0.001\right)$. This phenomenon would appear to indicate a beneficial impact on leaf growth of nutrient inputs resulting from marine fish farming, as has already been reported for other marine phanerogams $[7,26]$.

At all the stations situated in proximity of facilities, the leaves of Posidonia oceanica are covered with a dense layer of epiphytes. Maximum coverage was observed between 20 and $80 \mathrm{~m}$ at the Bay of Figari, and is confirmed by the biomass values (figure 8 ). In addition, the mean biomass is lower at Aranci than at Figari. This corroborates the fact that epiphyte development is directly correlated with the amount of nutrients and light available in the environment $[6,9,20,33]$. Paradoxically, the fact that the epiphyte coverage is not at its maximum beneath facilities (where the nutrient input is maximum) may be explained by the large quantities of copper introduced with the food ( 400 to $450 \mathrm{~kg}$ of copper per year at the Figari site), which might act as an inhibiting factor for the growth of the algal component of the epiphytic community.

Coefficient A, which represents the impact of herbivores (fish, echinoderms, crustaceans), is relatively low at the

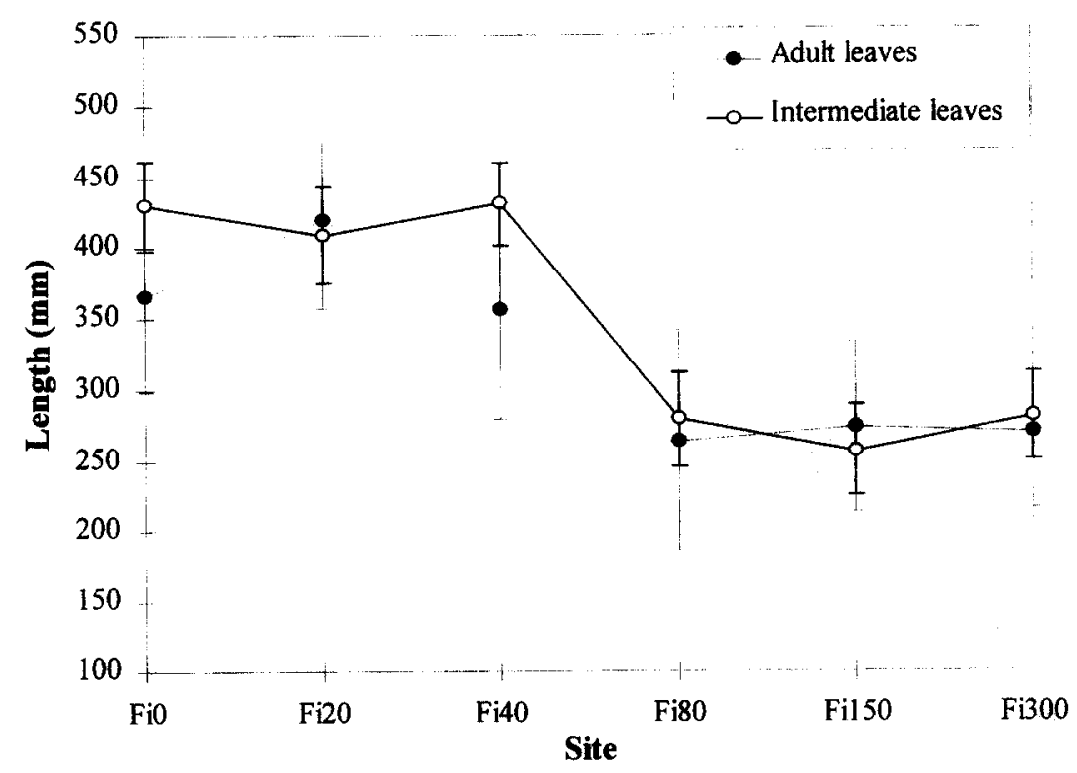

Figure 7. Changes in the mean leaf length of adult and intermediate leaves in relation to distance from facilities in the Bay of Figari in May 1994. Bars indicate confidence intervals. 


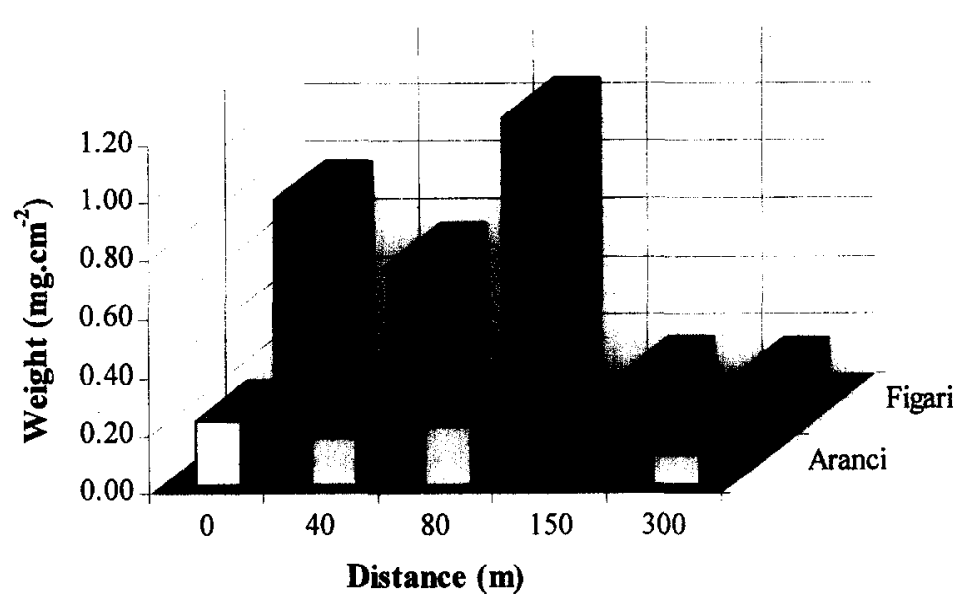

Figure 8. Biomass of epiphytes on adult leaves of Posidonia oceanica in June 1994, in relation to the distance from facilities.

sites studied compared with values reported in the literature $[14,28,29]$. Nevertheless, it shows a significant increase in proximity $(0-40 \mathrm{~m})$ to the aquaculture facilities (figure 9). This gradient may be explained by the high density of the fish fauna observed during dives in the vicinity of the fish farm. The enrichment of the environment the result of inputs of organic matter from the facil- ities (e.g. excretion, unconsummed food, etc.) favours (i) the development of an associated fauna [8, 31], and (ii) an increase in the epiphytic cover of the Posidonia oceanica leaves. The epiphytic cover represents an important source of food for the herbivorous species, especially the fish Sarpa salpa (Linnaeus, 1758), which leaves clearly visible traces on the Posidonia oceanica leaves.

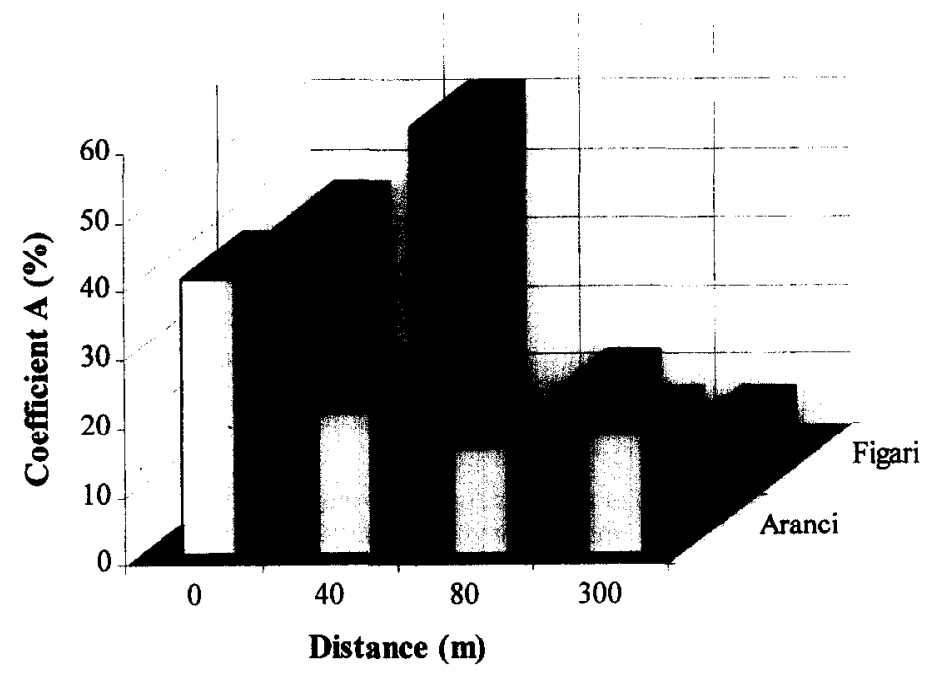

Figure 9. Changes in overall Coefficient A (adult and intermediary leaves) in relation to the distance from facilities in the Bay of Figari and the Gulf of Aranci, June 1994. 
The number of leaves produced annually, as estimated by lepidochronology, increases with depth: $7.0 \pm 0.2$ at Sant'Amanza (6 m depth), $7.5 \pm 0.1$ al Figari (9 ml depth) and $8.0 \pm 0.2$ at Aranci (23 m depth). However, neither the opening of the fish farms, nor the distance from facilities result in any significant alterations of this parameter.

The maximum growth rate of the orthotropic rhizomes was recorded in the Bay of Figari $(4.9 \pm 0.3 \mathrm{~mm}$ per year), which is characterised by massive inputs of organic matter and terrigenous sediment (outfall of river, sewage treatment plant and fish farming facilities). This would tend to confirm the relationship existing between the growth rate of the rhizomes and the sedimentation rate $[4,10]$. Because of the various origins of these inputs, it is impossible to distinguish the actual impact of the inputs generated by the fish farms. For the stations situated in the Gulf of Sant'Amanza, where the terrigenous inputs are weaker, the mean growth rate is lower (less than $4.1 \pm 0.2 \mathrm{~mm}$ per year). The growth rate of rhizomes at both Figari and Sant'Amanza appears to be fairly low as compared to those values provided for other regions in the Mediterranean (table IV).

Table IV. Interpretation of growth rate of Posidonia oceanica rhizomes (according to Pergent et al. [29])

\begin{tabular}{cc}
\hline $\begin{array}{c}\text { Growth rate } \\
\text { (mm per year) }\end{array}$ & Interpretation \\
\hline $\begin{array}{c}5.9 \text { to } 8.9 \\
3.7 \text { to } 5.9 \text { and } 8.9 \text { to } 11.1\end{array}$ & $\begin{array}{c}\text { Normal value } \\
<3.7 \text { and }>11.1\end{array}$ \\
\hline
\end{tabular}

While no comparable tendency is apparent in the sheaths, a decrease in these concentrations can be noted in the rhizomes at a distance from facilities (table V; figure 10). In parallel, an increase in concentrations of both of these metals has been recorded in the rhizomes of Posidonia oceanica since the opening of the facilities (figure 11). The phenomenon probably retlects isolated cases of pollution of the sites resulting from food inputs associated with fish farming. These observations are an integral part of the bioaccumulation properties of Posidonia oceanica with regard to trace metals $[30,32]$. Nevertheless, because these metals play an active role in the metabolism of the plant (essential metals) their respective concentration may equally reflect a particular physiological situation, and further studies are required to confirm this hypothesis.

\section{CONCLUSION}

The results obtained confirm the impact of aquaculture facilities on the environment. In the water column, a general increase in turbidity and an enrichment of the sediment in organic matter and nutrients has been recorded. While these observations are quite similar to those reported in other regions of the world $[13,16,18]$, the impact on the Posidonia oceanica meadows are reported here for the first time. While food input into waters generally considered as oligotrophic may appear to be a positive factor, resulting in an increase in the mean length of the leaves, the epiphytic biomass and the associated fish fauna, the decrease in the density of the meadows they cause in proximity to these facilities, or even their total disappearance beneath facilities, is particularly disturbing.

The combined use of different environmental descriptors (water, sediment, Posidonia oceanica meadow) makes it possible to identify various parameters that are capable of determining the area of impact of the fish farms. For example, analysis of concentrations of ammonium, chlorophyll $a$ and phaeopigments for the sediment, and estimation of the density, epiphyte biomass and certain biometric parameters for the meadow have been used with success. In addition, because of its ability to accumulate and memorise trace metals (present in the feeds), the Posidonia oceanica meadow is a powerful bioindicator for spatial and temporal monitoring of the impact of the fish farms.

Table V. Concentrations of trace metals ( $\mu \mathrm{g} \mathrm{g}^{-1}$ dry weight) in the sheaths and rhizomes of Posidonia oceanica, in the Gulf of Sant'Amanza and the Bay of Figari. The mean is calculated from tissues formed between 1987 and 1992 (dating by lepidochronology). Values are expressed as mean \pm confidence intervals.

\begin{tabular}{lrrrrr}
\hline Site & \multicolumn{2}{c}{ Sheaths } & \multicolumn{2}{c}{ Rhizomes } \\
& Copper & Zinc & Copper & Zinc \\
\hline Sant'Amanza & $8.29 \pm 1.67$ & $39.14 \pm 5.65$ & $4.15 \pm 0.77$ & $21.90 \pm 4.35$ \\
Figari & $14.34 \pm 2.69$ & $59.47 \pm 7.47$ & $2.84 \pm 0.46$ & $60.41 \pm 11.21$ \\
\hline
\end{tabular}




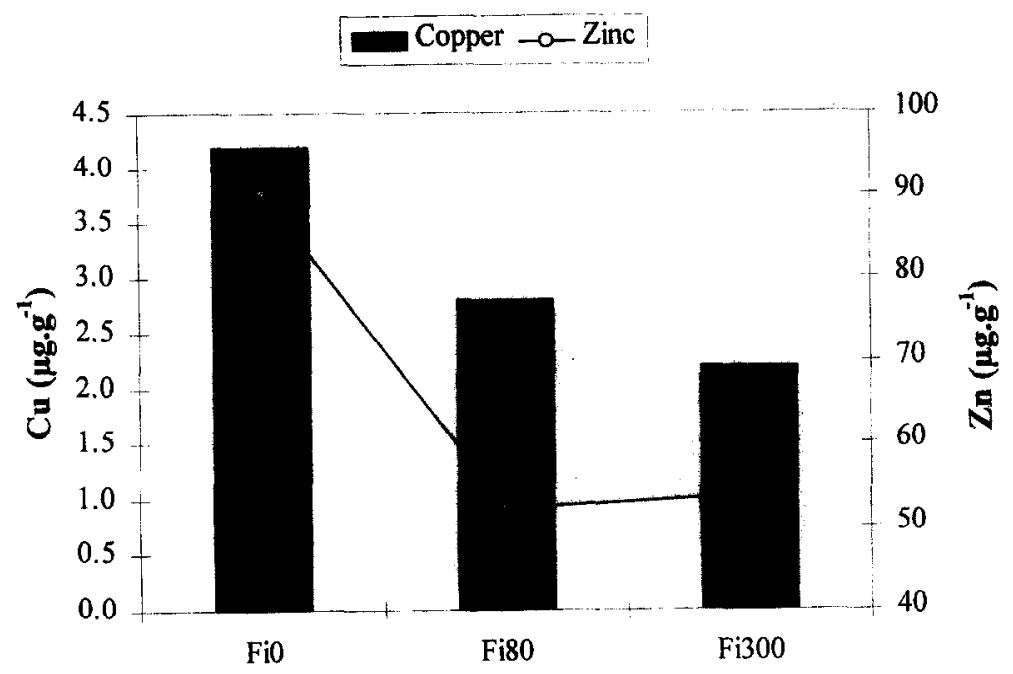

Figure 10. Concentrations of copper and zinc $\left(\mu \mathrm{g} \mathrm{g}^{-1}\right.$ dry weight) in rhizomes of Posidonia oceanica in relation to the distance from facilities in the Bay of Figari.

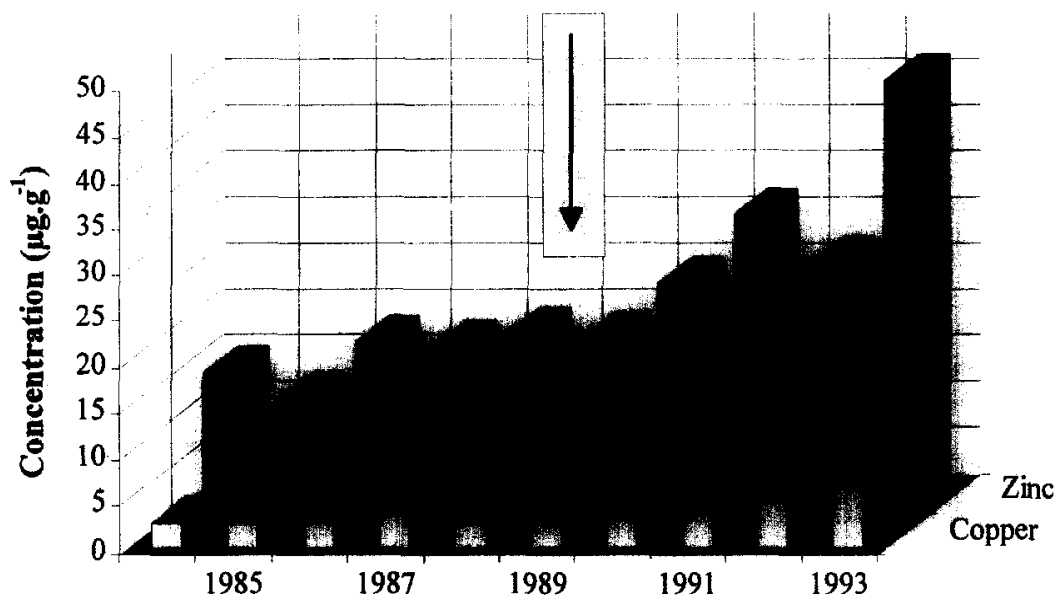

Figure 11. Copper and zinc concentrations ( $\mu \mathrm{g} \mathrm{g} \mathrm{g}^{-1}$ dry weight) in the rhizomes of Posidonia oceanica over time in the Gulf of Sant'Amanza. The arrow indicates the year of opening of the fish farm.

While the impact on the littoral environment appears to be limited to a few hundred metres for the smaller facilities, it cannot be considered as insignificant, since it can result in the relatively rapid dccline of Posidonia oceanica meadows under certain conditions (e.g. Gulf of Aranci).
In the context of the development of aquaculture facilities along the Mediterranean coast, it is therefore necessary that measures be taken to minimise this impact. The legislation of various countries regarding the protection of certain species may indeed constitute an insurmountable obstacle to the establishment of new fish farms [5]. While 

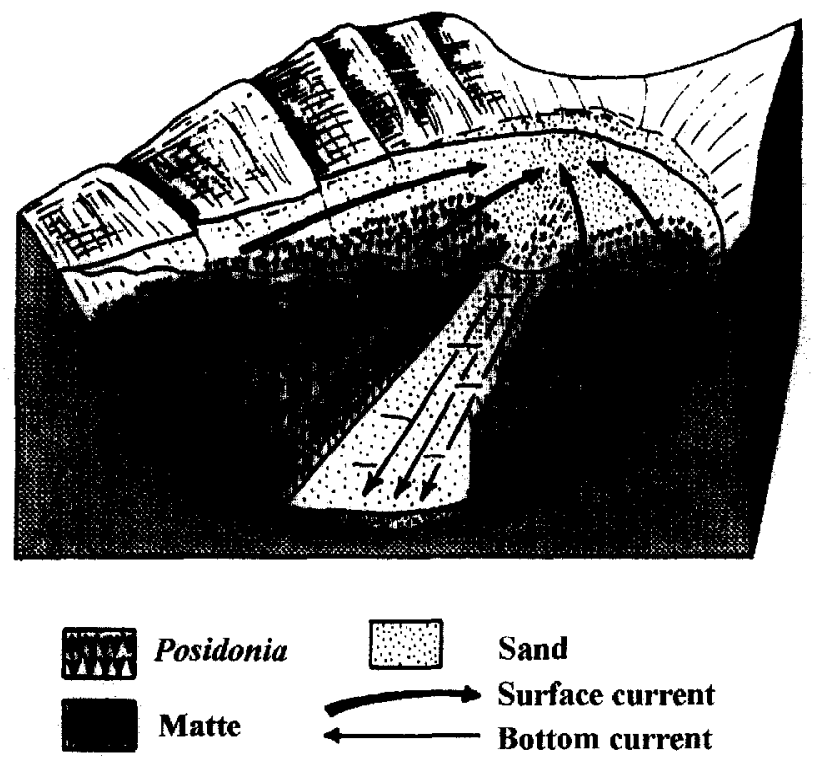

Figure 12. Theoretical block diagram of a tidal river in a bay exposed to dominant winds [3]. it is thus difficult to envisage the setting up of new farms directly above Posidonia oceanica beds, the existence in certain sheltered bays of large tidal rivers might offer an interesting alternative (figure 12). This type of structure. characterised by a central channel with a bed of coarse sand, with strong circulation of water at the bottom (in a seaward direction), should allow sufficiently rapid dispersion of particles to limit the impact on the environment.

\section{Acknowledgements}

The study, carried out in collaboration with IFREMERBrest (M. Kempf) and Corsica (M. Angeli), received financial support from a European programme supporting scientific cooperation between Corsica and Sardinia (INTERREG). The authors are particularly grateful to $\mathrm{Mr}$ Tomasi and Mr Di Cristo, the managers of the aquaculture facilities at Figari and Sant'Amanza, and Professor Cottiglia of the University of Cagliari (Sardinia).
[1] Arnoux A., Analyse de polluants dans les sédiments et des organismes du site de Cortiou-Campagne de prélèvement juillet 1987, Lab. Hydrologie et Molysmologie aquatique, faculté de pharmacie, univ. Aix-Marseille-II : 86p. +35 pl. annexes (1987).

[2] Bacquer J.M., L'aquaculture en Corse en 1992 : technique et économie, in "Agriculture et aquaculture, aspect juridique et économique", Loysel Ed., Association droit rural région Corse Publ. (1992) 167-172.

[3] Boudourcsque C.F., Meinesz A., Découverte de l'herbier de Posidonies, Parc nation. Port-Cros éd., Cahier découverte, 4 (1982) 1-79.

[4] Boudouresque C.F., Jeudy de Grissac A., Meinesz A., Relation entre la sédimentation et l'allongement des rhizomes orthotropes de Posidonia oceanica dans la baie d'Elbu (Corse), International Workshop on Posidonia oceanica Beds, Boudouresque C.F., Jeudy de Grissac A., and Olivier J., (Eds.), GIS Posidonie publ. 1 (1984) 185-191.

[5] Boudouresque C.F., Gravez V., Meinesz A., Molenaar H., Pergent G., Vitiello P. L'herbier à Posidonia oceanica en Méditerranée : protection légale et gestion, in: "Pour qui la Méditerranée au $\mathrm{XXI}^{\mathrm{e}}$ siècle, Villes des rivages et environnement littoral en Méditerranée", OKEANOS 94, Maison de l'Environnement de Montpellier (éd.) (1995) 209-220.

[6] Buia M.C., Zupo V., Mazzella L. Primary production and growth dynamics of Posidonia oceanica, Mar. Ecol., PSZNI, 13,1 (1992) 2-16.
[7] Bulthuis D.A., Woelkerling W.M.J., Effects of in situ nitrogen and phosphorus enrichment of the sediments on the seagrass Heterozostera tasmanica (Martens ex Aschers.) Den Hartog in Western Port, Victoria, Australia, J. Exp. Mar. Biol. Ecol. 53 (1981) 193-207.

[8] Cam D., Détermination des contributions relatives de la productivité naturelle et de l'aliment à la ration alimentaire de la crevette Penaeus japonicus élevée en conditions semi-intensives, ICES, C. M 19889/K (1987) 22.

[9] Cambridge M.L., Chiffings A.W., Brittan C., Moore L., Mc Comb A.J. The loss of seagrass in Cockburn Sound, Western Australia II, Possible causes of seagrass decline, Aquat. Bot. 24 (1986) 269-285.

[10] Caye G., Étude sur la croissance de la Posidonie, Posidonia oceanica (L.) Delile, formation des feuilles et croissance des tiges au cours d'une année, Téthys 10, 3 (1982) 229-235.

[11] De La Pomélie C., Les productions marines en Méditerranée française, Eaux 39 (1991) 44-46.

[12) Drew E.A., Jupp B.P., Some aspects of the growth of Posidonia oceanica in Malta, Underwater Research, Academic Press, London, 1976, pp.357-367.

[13] Flaherty M., Karnjanakesorn C., Marine shrimp aquaculture and natural resource degradation in Thailand, Environ Manage 19 (1) (1995) $27-37$. 
[14] Giraud G., Sur une méthode de mesure et de comptage des structures foliaires de Posidonia oceanica (Linnaeus) Delile. Bull. Mus. Hist. Nat. Marseille 39 (1979) 33-39.

[15] Gowen R.J., Bradbury N.B., The ecological impact of salmonid farming in coastal waters: A review, Oceanogr. Mar. Biol. Ann. Rev. 25 (1987) 563-575.

[16] Grant J., Hatcher A., Scott D.B., Pocklington P., Schafer C.T., Winters G.V., A multidisciplinary approach to evaluating impacts of shellfish aquaculture on benthic communities, Estuaries 18, 1A (1995) 124-144.

[17] Hall O.J., Holby O.L.H., Environmental impact of a marine fishcage culture, ICES, Mariculture Committee, CM 1986/F, 46 (1986) 14 pp.

[18] Hatcher A., Grant J., Schofield B., Effects of suspended mussel culture (Mytilus spp) on sedimentation, benthic respiration and sediment nutrient dynamics in a coastal bay, Mar. Ecol. Progr. Ser. 115 (3) (1994) 219-235.

[19] Krost P., Chrzan T., Schomann H., Rosenthal H., Effects of a floating fish farm in Kiel Fjord on the sediment, J. Appl. Ichthyol. 10 (4) (1994) 353-361.

[20] Larkum A.W., Ecology of Botany Bay I. Growth of Posidonia australis (Brown) Hook F, in Botany Bay and other Bays of Sydney Basin, Aust. J. Mar. Frehwater Res. 27 (1976) 117 127.

[21] Leach J.H., Epibenthic algal production in a intertidal mudflat, Limmol. Oceanogr. 15 (4) (1970) 514-521.

[22] Meinesz A., Laurent R., Cartographie et état de la limite inférieure de l'herbier de Posidonia oceanica dans les Alpes-maritimes (France), Campagne Poséidon 1976, Bot. Mar. 21 (8) (1978) 513-526.

[23] Merceron M., Kempf M., Environmental quality of a salmonid farm site in a flushed area (Cherbourg, France), in "Quality in aquaculture", European Aquaculture Soc. Publ. 23 (1995) 258-259.

[24] Munday B.W., Eleftheriou A., Kentouri M., Divanach P., Quantitative statistical analysis of the literature concerning the interaction of the environment and aquaculture, Identification of gaps and lacks, J. Appl. Ichthyol. 10 (4) (1994) 319-325.
[25] Ott J.A., Growth and Production in Posidonia oceanica (L.) Delile, Mar. Ecol. PSZNI 1 (1980) 47-64.

[26] Perez M., Duarte C.M., Romero J., Sand-Jensen K., Alcoverro T. Growth plasticity in Cymodocea nodosa stands : the importance of nutrient supply, Aquat. Bot. 47 (1994) 249-264.

[27] Pergent G., Boudouresque C.F., Crouzet A., Meinesz A., Cyclic changes along Posidonia oceanica rhizomes (Lepidochronology): Present state and perspectives, Mar. Ecol. PSZNI 10 (3) (1989) 221-230.

[28] Pergent G., Pergent-Martini C., Phénologie de Posidonia oceanica (Linnaeus) Delile dans le bassin méditerranéen, Ann. Inst. océanogr. 64 (2) (1988) 79-100.

[29] Pergent G., Pergent-Martini C., Boudouresque C.F. Utilisation de l'herbier à Posidonia oceanica comme indicateur biologique de la qualité du milieu littoral en Méditerranée : état des connaissances, Mésogée 54 (1995) 3-27.

[30] Pergent-Martini C., Pergent G., Lepidochronological analysis in the Mediterranean seagrass Posidonia oceanica : State of the art and future developments, Oceanol. Acta 17 (6) (1995) 673 681 .

[31] Reymond H., Lagardère J.P., Feeding rhytms and food of Penaeus Japonicus bate (Crustacea, Peneidae) in salt marsh : role of halophilic entomofauna, Aquaculture 84 (1990) 125143.

[32] Romeo M., Gnassia-Barelli M., Juhel T., Meinesz A., Memorization of heavy metals by scales of the seagrass Posidonia oceanica, collected in the NW Mediterranean, Mar. EcolProgr. Ser. 120 (1-3) (1995) 211-218.

[33] Sand-Jensen K., Borum J., Regulation of growth of eelgrass (Zostera marina L.) in Danish waters, Mar. Soc. Tech. J. 17 (1983) 15-21.

[34] Strickland J.D.H., Parsons T.R., A practical handbook of seawater analysis, Fish. Res. Bd. Canada, Bull. 167 (1968) $311 \mathrm{p}$.

[35] Wu R.S.S., The environmental impact of marine fish culture: Towards a sustainable future, Mar. Pollut. Bull. 31 (4-12) (1995) 159-166. 